
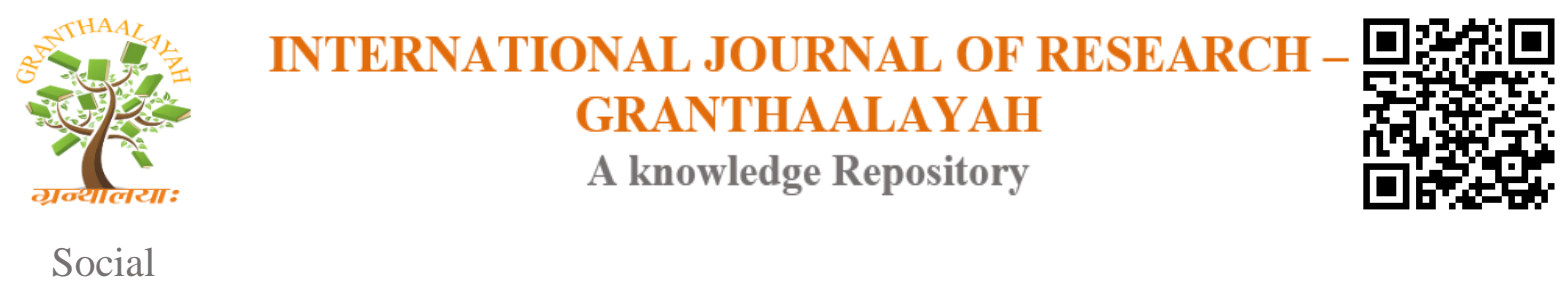

\title{
INVESTIGATION OF THE EFFECTIVENESS OF USING SELF- DETERMINATION THEORY IN TEACHING SCIENCE FOR GRADE EIGHT STUDENTS: A CASE STUDY IN SRI LANKA
}

\author{
Avanthi Jayarathne ${ }^{1}$, W. D. Chandrasena *2 \\ ${ }^{1}$ Postgraduate Institute of Science, University of Peradeniya, Sri Lanka \\ ${ }^{* 2}$ Science Education Unit, Faculty of Science, University of Peradeniya, Sri Lanka
}

\begin{abstract}
Science is highly important as it focusses on enhancing the quality of human life. Though, science is perceived to be an interesting discipline, students' performance in the field of school science is not very satisfactory. Self-determination theory (SDT) assumes that inherent in human nature is the propensity to be curious about one's environment and interested in learning and developing one's knowledge. Thus, SDT can be used to teach science effectively in classrooms to enhance students' performance. As described in SDT, people have three innate psychological needs; competence, autonomy and relatedness. If these needs are fulfilled, the optimal functioning of human beings can be obtained. Hence, this study focused in investigating the effectiveness of using SDT in teaching "Main Biological Processes in Plants" for Grade 8 students. The study was conducted using two groups of students as the experimental and the control. The experimental group was instructed using SDT while the control group was taught using traditional method. The students' performance, psychological relatedness, competence, and the autonomy showed higher in the experimental group compared to the control group. Thus, the results indicate that the instructional approach based on SDT is very effective compared to traditional approach of instruction in teaching science as SDT approach develops intrinsic motivation of students.
\end{abstract}

Keywords: Investigation; Effectiveness; Determination; Eight Students.

Cite This Article: Avanthi Jayarathne, and W. D. Chandrasena. (2019). "INVESTIGATION OF THE EFFECTIVENESS OF USING SELF-DETERMINATION THEORY IN TEACHING SCIENCE FOR GRADE EIGHT STUDENTS: A CASE STUDY IN SRI LANKA." International Journal of Research - Granthaalayah, 7(4), 126-131.

\section{Introduction}

Learning biological science has important implications for human society. It is really important to everyday life as it fundamentally is the systematic study of the structure and behavior of the natural and physical world through observations and experiments. It encompasses the cellular basis of living things, the energy metabolism that underlies the activities of life, and the genetic basis for inheritance in organisms in the world. 
As it is such important, it has been included in the school curriculum of Sri Lanka from Grade 6 to 11 as a main subject component. Science is perceived to be an interesting field but the students' performances of their skills in the field of Science is not very satisfactory in Sri Lanka. This may be due to different reasons such as changes in the curriculum, the time allocated for each science topic, the teachers' teaching load, resources available, lack of specialized content knowledge with the educators, the medium of instruction, the involvement of the parents, poverty, and motivation. There are three dimensions of science education. The first is the content of science incorporating the basic concepts, and scientific knowledge. The other two are the science processes and attitudes (Yockey, 2001). As science is everywhere the importance of a having an informed citizenry that understands science is really important.

Self-determination theory (SDT) maintains that an understanding of human motivation requires a consideration of innate psychological needs for competence, autonomy, and relatedness (Deci \& Ryan, 1985; 2000; 2000b). It assumes that inherent in human nature is the propensity to be curious about one's environment and interested in learning and developing one's knowledge (Christopher, Niemiec, \& Ryan, 2009). Thus, SDT can be used to teach science effectively in classrooms to enhance students' skills in science (Ahn, 2014; Perlman, 2013). It suggests that both intrinsic motivation and autonomous type of extrinsic motivation are conducive to engagement and optimal learning in educational contexts. As described in SDT, people have three innate psychological needs; competence, autonomy, and relatedness. If these needs are fulfilled, the optimal functioning of human beings can be obtained. The foundation of SDT is that the extent of basic psychological needs satisfaction determines the level of psychological growth and well-being. The above needs should be fulfilled to optimize the students' inherent potential in the school classrooms.

There is a dearth of research and practices that have been developed using SDT in Sri Lankan school classroom context. Thus, this study is focused in investigating the effectiveness of using SDT in teaching "Main Biological Processes in Plants" for Grade 8 students. Hence, the aim of this study was to teach "Main Biological Processes in Plants" for Grade Eight students using SelfDetermination Theory to investigate the effectiveness of learning so as to make suggestions to improve Science teaching and learning process. The objectives of this study were to: Investigate Grade Eight students' motivation \& prior knowledge on "Main Biological Processes in Plants"; Plan the lessons for control \& experimental groups on Grade Eight "Main Biological Processes in Plants"; Conduct lessons on "Main Biological Processes in Plants" for both control \& experimental groups; Find the effectiveness of teaching using Self- Determination Theory for experimental group compared to control group; and Make suggestions to enhance students' learning process on "Main Biological Processes in Plants".

\section{Methodology}

\subsection{Method}

Mixed methods approach was used in this study considering the advantages of data triangulation in making conclusions. This experimental study was conducted using two groups of students as the experimental and the control. 


\subsection{Data Collection}

\section{Sampling}

Convenience sampling technique was used. The sample consisted of 150 Grade 8 students divided into two groups as experimental and control based on the pre-test marks. Sample was drawn from a school in Sabaragamuwa province, Sri Lanka.

\section{Instrumentation}

Students' self-concepts, motivation, and aspirations were explored using a validated questionnaire (Chandrasena, Craven, Tracey, \& Dillon, 2014). Autonomy support, psychological relatedness support, competence support were assessed by the Learning Climate Questionnaires (LCQ) developed by Standage, Duda, and Ntoumainis in 2005. Students' academic performance was explored using test marks. Classroom observations were made using an observation schedule.

\section{Procedure}

The unit of "Main Biological Processes in Plants" in Grade 8 syllabus was selected to study the effectiveness of SDT in teaching Science. The knowledge of "Main Biological Processes in Plants" is really important for the students who learn science. The selected unit of the syllabus was taught in the second term as it is scheduled for the second term. The experimental group was instructed using SDT and while the control group was instructed in the traditional method. The lessons were planned according to 5E model and the lessons for experimental groups were planned in order to enhance students' intrinsic motivation by giving the students opportunities to fulfill autonomy, competency and relatedness. The lessons for the control group were planned as lectures and discussions.

First the prior knowledge of the students about the "Main Biological Processes in Plants" was tested using a pre-test that was prepared according to the short answers technique. Questionnaire of self-concepts, motivation \& aspiration was administered to both groups to check the students' prior motivation for the learning that particular subject content. During the lessons students' facial expressions, interaction with other students, their unity when they perform their team work, behaviours and reactions to the teacher when asking questions, politeness, initiation were observed and field notes were maintained. The semi-structured interviews were conducted for focus groups of Grade 8 students in both experimental and control groups. In addition to that photograph and videos were taken with the help of another teacher. A post-test was conducted to assess the performance of their learning and questionnaire on self-concepts, motivation \& aspiration was administered to both groups to check their motivation on the subject component after the intervention. The autonomy support, psychological relatedness support, and competence support of the both groups were assessed by the Learning Climate Questionnaires (LCQ).

\section{Data Analysis}

The qualitative data were analyzed using thematic analysis and the quantitative data were analyzed using SPSS for descriptives, correlation and regression. Students' self-concepts, motivation, aspiration, performance, autonomy support, psychological relatedness support, and competence support in both groups were compared using independent sample t-test. 


\section{Results and Discussion}

The results of the pre-test and the post-tests of the study showed that there is a significant difference in the post test marks of the experimental group compared to the control group.

Table 1: Mean values of Pre-test and Post-test marks

\begin{tabular}{|l|l|l|}
\hline Group & $\begin{array}{l}\text { Mean values of the } \\
\text { pre-test marks }\end{array}$ & $\begin{array}{l}\text { Mean values of the } \\
\text { post-test marks }\end{array}$ \\
\hline Experimental & 35.07 & 83.46 \\
\hline Control & 34.73 & 63.49 \\
\hline
\end{tabular}

As shown in the above (Table 1) mean values of the post-test marks of the experimental group and control group are 83.46 and 63.49 respectively. Thus, there is a significant increase of the marks of the students who were taught using SDT. According to the independent sample t-test there is no significant difference in the pre-test marks in the both groups where $t(148)=0.126, p>0.05$. However, there is a significant difference in the post-test marks for the two groups where $t(148)=$ 7.901, $\mathrm{p}<0.05$.

In the questionnaire given to explore the students' motivation, self-concepts and aspiration, the students' mastery, intrinsic and ego motivations were administered. The results obtained through the questionnaire revealed higher improvement of the students' characteristics such as motivation, self-concepts, aspiration, engagement, and enthusiasm in education in the experimental group compared to the control group.

Table 2: Mean values of Motivation before and after the Intervention

\begin{tabular}{|l|l|l|l|}
\hline Group & Types of motivation & $\begin{array}{l}\text { Mean values before the } \\
\text { Intervention }\end{array}$ & $\begin{array}{l}\text { Mean values after the } \\
\text { Intervention }\end{array}$ \\
\hline Experimental & $\begin{array}{l}\text { Intrinsic motivation } \\
\text { in Science }\end{array}$ & 2.8509 & 3.1911 \\
\cline { 2 - 4 } Mastery motivation & 3.1316 & 3.3289 \\
in Science & $\begin{array}{l}\text { Ego motivation in } \\
\text { Science }\end{array}$ & 3.2259 \\
\hline Control & $\begin{array}{l}\text { Intrinsic motivation } \\
\text { in Science }\end{array}$ & $\begin{array}{l}\text { Mastery motivation } \\
\text { in Science }\end{array}$ & 2.01396 \\
\cline { 2 - 4 } Ego motivation in 2.8851 & 2.9543 \\
Science & 2.7275 \\
\hline
\end{tabular}

According to the above table (Table 2) students' intrinsic motivation, mastery motivation, and the ego motivation in the experimental group have increased after the lessons were conducted using SDT. However, in the control group all the motivational types show a decrease which was taught in the traditional method. Students in the experimental group were highly motivated and frequently asked to conduct science lessons in other periods as well. They showed their willingness to perform group activities, presentations and field work. 
The teacher's autonomy support, competence support, and the relatedness support on the students also were tested using LCQ and that results revealed that the experimental group who are taught using SDT is highly motivated and their competence, autonomy and relatedness have increased compared to the control group (Table 3).

Table 3: Mean values of Support before and after the Intervention

\begin{tabular}{|l|l|l|}
\hline Group & Types of support & Mean values \\
\hline Experimental & Autonomy support & 5.7605 \\
\cline { 2 - 3 } & Competence support & 6.3191 \\
\cline { 2 - 3 } & Relatedness support & 6.3632 \\
\hline \multirow{3}{*}{ Control } & Autonomy support & 5.1198 \\
\cline { 2 - 3 } & Competence support & 5.3345 \\
\cline { 2 - 3 } & Relatedness support & 5.1324 \\
\hline
\end{tabular}

The results of the LCQ show that the autonomy support, the competence support and the relatedness support for the experimental group are really higher than the control group. The highest mean value can be seen in the relatedness support thus it would be advantageous to motivate students through group work. The maximum mean value of the competence support is 6.3191 . According to this observation most of the students have perform their studies willingly and they have improved their skills on the subject content. Thus, the classroom practices based on the SDT can be used as a good technique of classroom instruction in teaching science in order to enhance the students' intrinsic motivation.

\section{Conclusions and Suggestions}

According to the results the students' psychological relatedness, competence, and autonomy support have improved with the application of Self Determination Theory in Sri Lankan classroom context to teach science. Moreover, it is important to create a good learning environment in the science classrooms for meaningful learning. Thus, the use of SDT is highly useful in generating an effective teaching and learning environment in schools to meet the educational goals successfully.

\section{References}

[1] Ahn, I. (2014). Relations between teachers' motivation and students' motivation: A self determination theory perspective. Open access Thesis 725. retrieved from http// docs.purdue.edu/ open_thesis/725(accessed 18, July, 2018).

[2] Chandrasena, W., Craven, R., Tracey D., \& Dillon, A. (2014). Seeding Science Success: Psychometric Properties of Secondary Science Questionnaire on Students' Self-Concept, Motivation, and Aspirations. Australian Journal of Educational \& Developmental Psychology, 14, pp. 186-201.

[3] Christopher P. Niemiec and Richard M. Ryan (2009). Autonomy, competence, and relatedness in the classroom. Applying self-determination theory to educational practice. Vol 7(2) 133-144 ISSN 1477-8785 DOI: $10.1177 / 1477878509104318$

[4] Deci, E. L., \& Ryan, R. M. (1985). Intrinsic motivation and self-determination in human behavior. New York, NY: Plenum. 
[5] Deci, E. L., \& Ryan, R. M. (2000). The "what" and "why" of goal pursuits: Human needs and the self-determination of behavior. Psychological Inquiry, 11, 227-268.

[6] Perlman, D. J. (2013). Effective teaching and motivation: application of self-determination theory. Journal of Research, Policy \& Practice of Teachers \& Teacher Education, 3 (2), 31-37.

[7] Ryan, R. M., \& Deci, E. L. (2000). Self-determination theory and the facilitation of intrinsic motivation, social development, and well-being. American Psychologist, 55, 68-78.

[8] Ryan, R. M., \& Deci, E. L. (2000b). Self-determination theory and the facilitation of intrinsic motivation, social development, and well-being. American Psychologist, 55, 68-78.

[9] Standage, M., Duda, J. L., \& Ntoumainis, N. (2005). A test of self-determination theory in school psychological education. British Journal of Educational Psychology, 75, 411-433. doi:10.1348/000709904X22359

[10] Yockey, J. A. (2001). A Key to Science Learning. Science \& Children, 38(7), 36-41.

\footnotetext{
*Corresponding author.

E-mail address: wdchand@ pdn.ac.lk
} 